\title{
ASPECTES DE MORFOSINTAXI EN UNS PROCESSOS CRIMINALS \\ VALENCIANS DEL TERCER QUART DEL SEGLE XVI ${ }^{1}$ \\ Joaquim Martí Mestre \\ Universitat de València
}

\section{INTRODUCCIÓ}

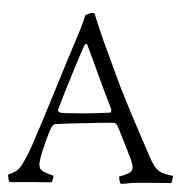

partir de vint-i-quatre processos criminals inèdits sobre agressions i injúries situats entre 1552 i 1571, procedents de la ciutat de València, estudiem alguns aspectes de morfosintaxi sobre l'article, els pronoms personals, els possessius, els demostratius, els quantificadors, els relatius i els verbs.

Els processos es troben entre els textos que amb més propietat permeten aproximar-se a la llengua parlada i colloquial del passat (cf. MiralleS: 1984; MONTOYA: 1990; FRESQUET: 1997; RABELLA: 1998; FARRENY: 1986, 2004). Encara que les declaracions dels denunciants, testimonis i acusats s'han de llegir a través de la transcripció dels escrivans, la base de la qual parteixen, que constitueix el nucli del procés, són les declaracions orals de persones diverses, moltes pertanyents a les classes populars, que s'expressen espontàniament, sovint fent servir un registre colloquial.

En els processos conviuen diferents tipus textuals, amb graus de formalitat diversos, des de les declaracions dels testimonis en estil directe fins als formulismes jurídics. En els processos en els quals es basa aquest treball, procedents de l'Arxiu del Regne de València (ARV, Secció Processos criminals, II part), ${ }^{2}$ es poden trobar les parts següents: el clam oral

\footnotetext{
${ }^{1}$ Aquest article forma part del Projecte PGC2018-097011-B-I00 «Biografías marginales: violencia, sexo, género e identidad. Edición y análisis de las fuentes documentales valencianas de la época foral», del Ministerio de Ciencia, Innovación y Universidades del Gobierno de España, i del Projecte AICO2019/120 «Violència de gènere i identitats: edició i estudi de documentació valenciana per a la construcció de biografies marginals (s. XV-XVI)», de la Conselleria d'Innovació, Universitats, Ciència i Societat Digital de la Generalitat Valenciana.

${ }^{2}$ En concret, estudiem els processos següents: Caixa 7, exp. 55 (1552), exp. 62 (1553); caixa 10, exp. 92 (1557); caixa 12, exp. 118, 126 (1561); caixa 13, exp. 132 (1561); caixa 14, exp. 147 (1562); caixa 17, exp. 180 (1564); caixa 75, exp. 883 (1565); caixa 20, exp. 213 (1566); caixa 75, exp. 873, 876 (1567); caixa 28, exp. 258, 261 (1571);
} 
dels denunciants, les declaracions orals dels testimonis, l'acusació presentada per escrit al jutge per part de l'individu afectat o del seu procurador, sota la fórmula de petits capítols, ${ }^{3}$ i les diligències jurídiques. Com diu Fresquet Fayos (1997), cal diferenciar també en els processos la narració de l'escrivà i la narració del testimoni, que correspon a la declaració de les diferents persones que presenten el seu testimoniatge, incloent-hi els acusats i els denunciants. En la declaració dels testimonis es pot diferenciar entre la redacció de l'escrivà a partir de la declaració dels testimonis, en estil indirecte, i la reproducció de la declaració dels testimonis, en estil directe. Hem de pensar que és en l'estil directe on l'aproximació a la parla real és major, però igualment la redacció dels escrivans en estil indirecte es basa en les paraules dels declarants, i, per tant, també conté elements col.loquials.

\section{ARTICLE}

\subsection{L'ARTICLE DETERMINAT MASCULÍ}

Les formes plenes lo i los són les més habituals en tots els processos. Es troben també les formes asil.làbiques $l \mathrm{i} l s$, però en els processos consultats no apareixen encara les reforçades el, els.

Les formes asil.làbiques es troben sobretot precedides de les preposicions a i de, formant les formes contractes al, del. ${ }^{4}$ Fora d'aquest context, són poc habituals, i només en recollim aquests casos, en els quals l'article singular es troba davant mots començats per vocal, en tres ocasions davant un substantiu començat per $o$ tònica, que afavoreix l'elisió de la $o$ de l'article: «per l'or» $(147,6),{ }^{5}$ «en l'ort» $(258,4 r)$, «l'orde de justícia» $(269,4)$, «davant l'altre» $(213,14)$; «entre.ls altres» $(819,8)$, «entre.ls quals» $(821,2)$.

caixa 29, exp. 269 (1571); caixa 75, exp. 811, 813, 818, 819, 821, 841, 845, 847, 849 (1571).

${ }^{3}$ Sobre el procediment judicial en la València medieval, vegeu Narbona Vizcaíno (1990, p. 43-49).

${ }^{4}$ En aquest cas no apareix mai l'article en forma plena.

${ }^{5}$ Citem els textos procedents dels processos amb el número del manuscrit seguit de la pàgina. 


\subsection{L'ARTICLE DETERMINAT FEMENÍ}

Generalment presenta la forma plena la. Ara bé, davant mots començats per la vocal $a$, com hem vist que ocorre amb l'article masculí singular, la identitat de timbre afavoreix l'elisió de la vocal àtona de l'article: «y l'altra» $(62,1 ; 92,7,14 ; 213,25)$, «e l'altra» $(132,16)$, «de l'altra» $(213,20)$, «que no l'altra» $(845,3)$, «l'ama» $(258,2 \mathrm{v})$, «l'a[r]ma» $(118,5)$, «per l’ànima» $(883,5)$. Aquesta elisió és majoritària davant l'indefinit altra, encara que també apareix «la altra» $(92,2,5)$, i, igualment, juntament amb els casos d'elisió es troben els que mantenen la forma plena de l'article femení, en els mateixos mots: «la ama» $(258,7 \mathrm{v})$, «la ànima» $(118,8 ; 818,2,4,7)$, i en altres es troba sempre l'article la: «la Avallada de Sent Francés» $(62,5,7)$, «la Argenteria» $(118,8)$, «la ajuda» $(180,3)$, «la adoberia» $(818,2,5,8,9,11)$, «la Aluderia» $(818,5)$, «la anaya» $(883,2)$, «la alteració» $(883,4)$.

\subsection{L'ARTICLE PERSONAL}

L'article personal masculí en en els processos estudiats apareix amb menestrals i amb integrants de l'administració de justícia. Ara bé, s'hi troba generalment en contextos més aviat formals. Així, el veiem bàsicament en tres circumstàncies: en la presentació formal dels declarants, acompanyat de fórmules de tractament protocolàries i en els clams per escrit (enfront dels clams i les declaracions orals, on els antropònims masculins solen anar sense article, deixant a banda les parts més formals, com la presentació dels declarants). Poden donar-se conjuntament els tres condicionants o només una part. Per ex. «lo dit en Pere Millà» (62, 21) i «aquell, dit en Pere Millà» (62, 22), en el clam per escrit, mentre que en la declaració oral dels testimonis va sempre sense article: «Pere Milà», «Milà»; «En Miquel Hieroni de Angulo, marganter» (92, 2), en la presentació formal del declarant en el clam verbal, mentre que en la resta del clam oral apareix sense article.

Com hem dit, pot formar part de fórmules de tractament protocolàries: lo honorable en (menestrals, verguers i verguetes), lo honorable e discret en (notaris), lo discret en (notaris), lo magnifich en (alguatzirs reials i escrivans). En alguns processos aquestes fórmules s'apliquen només a 
membres de l'administració de justícia, mentre que en altres la primera fórmula també es fa servir amb menestrals, però en aquest cas només en la presentació en el procés. ${ }^{6}$

Davant el nom de nobles i cavallers el tractament més habitual és el castellanitzant Don, tant en membres de la noblesa castellana o aragonesa, com de la valenciana, ex. «Lo noble Don Manuel Mercader, cavaller» (876, 4), «Don Pedro de Castellví, comanador de Montesa, fill de Don Gilabert de Castellví» (id., 6), «Lo noble Don Francisco Reyner, alguazir ordinari de sa majestat» $(118,24)$. Només en una ocasió trobem l'article en amb un cavaller: «contra en Joan Ros, delat e denunciat» $(118,1)$, però la resta de vegades que apareix en el procés ho fa sense cap article o amb el tractament de mossén.

L'article personal femení na es troba amb dones de les classes populars (casades, vídues o solteres) i apareix preferentment en el mateixos contextos que el masculí, però en alguns processos té un ús abundant en el context que sembla reflectir millor la llengua oral, com són les declaracions orals, i apareix també en els fragments en estil directe. En aquests casos es troba sobretot davant del cognom o el sobrenom de la dona. Per ex., na Gilaberta, vídua de Jaume Gilabert, ${ }^{7}$ na Estévena («na Sthévena»), esposa de Jaume Esteve, ${ }^{8}$ na Serra i na Castilla, tots en 213; na Perisa $(269,9)$ i na Parisa (id., 3), probablement feminització de Peris; na Bielsa $(845,1)$, muller de Joan de Bielsa, na Miquela, na Vidala, na Ferràndiza i

\footnotetext{
${ }^{6}$ Barberà $(2018,273-275)$ també troba que l'article personal masculí en uns processos de la Ribera (1570-1599) s'usava sobretot en fórmules de tractament protocolàries, i pensa que amb aquest ús «ja no el podem considerar un article personal pròpiament dit, perquè fa la funció de fórmula de tractament protocolari».

${ }^{7}$ En un cas amb l'article literari: la Gilaberta $(213,13)$. Només tornem a trobar aquest article amb valor personal en un altre procés, amb una prostituta, la Ventura $(819,1,6)$, amb la qual no es fa servir mai l'article na. Potser tenia connotacions d'una major vulgaritat, i per això, segons el cas, es preferia na.

${ }^{8}$ Les dones sovint eren anomenades popularment amb el cognom del marit o del pare, feminitzats. Així, aquesta mateixa dona és anomenada també Margarida Gilaberta, pel cognom del pare. Encara que més rarament també podien ser conegudes pel nom de fonts del marit o del pare feminitzats: «na Eulàr[i]a Matheua, muller de Matheu Domingo, moliner» $(258,4)$ i la seua filla Caterina Mateua.
} 
na Pascuala (803). L'ús amb sobrenoms populars confirmaria la popularitat que encara mantenia l'article personal femení na.

També apareix, en fragments en estil directe, davant un nom comú usat com a vocatiu, que pren una funció propera al nom propi, fet servir com a insult o injúria: «Na bagassa, mala dona, jo us mataré ací en lo carrer!» $(126,3)$, «No cureu, na mala vella, que yo.l faré venir, a mon marit, y que os mate» $(213,6)$, «Na vil, bagassa, si munte aý, yo te cremaré la ca[s]a» $(213,12)$. De fet, en aquest context també es troba en una ocasió l'article personal masculí en: «Ha, en puto vellaco!» $(819,2)$.

Així, doncs, si atenem a la presència en els contextos més populars dels processos, com són les declaracions orals i l'estil directe, sembla conservar una major popularitat l'article femení na que el masculí en. Aquell hi era usat sobretot amb els cognoms i els sobrenoms, i també apareix davant noms comuns usats com a vocatius, cas en el qual també es troba, encara que amb menor freqüència, l'article en.

\section{PRONOMS PERSONALS}

En posició proclítica, precedits d'un mot acabat en consonant i seguits d'un verb començat per consonant (C-C), els pronoms febles mantenen sempre les formes plenes se, te, vos, lo, los, ne. Igualment, darrere d'un mot acabat en consonant i davant d'un verb començat en vocal (C$\mathrm{V})$ les formes plenes són les habituals, i tan sols en un cas documentem la forma elidida s': «delat, s'és jagut» $(258,10 \mathrm{r})$.

Precedits d'un mot acabat en vocal i davant d'un verb començat en consonant $(\mathrm{V}-\mathrm{C})$ les formes asil.làbiques $s, m, n, l, t$ es troben darrere d'alguns mots monosil-làbics de contingut gramatical: que (conjunció $\mathrm{i}$ pronom), els pronoms què i qui, l'adverbi no, les conjuncions $i(h i, y)$ i si i en un parell de casos del pronom yo. En canvi, darrere d'aquests mots no solen ser habituals les formes plenes de la majoria de pronoms, les quals

\footnotetext{
${ }^{9}$ Sobre l'evolució de l'article personal en català, veg. Casanova (2003), el qual afirma que en valencià «a mitjan segle XVI ja està en decadència», si bé es mantingué més «en les classes més baixes» i al segle XVII només «davant de dones».
} 
apareixen majoritàriament darrere mots polisíl.labs. ${ }^{10}$ Només el pronom te és més usat en forma plena en aquests casos: «yo te cremaré la ca[s]a» $(213,12)$, «yo te levaré» $(883,7)$ «no te vull» (id., 3, 7), «y te pegare» (id., 3), «y te levaré» (id., 3), i en forma reduïda només una vegada: «mira, que.t demanen» $(213,5)$.

En el context V-C es troba també la forma reduïda del pronom de segona persona plural us, darrere què, no i yo, ex. : «Ara hojats què us fan a saber» $(213,31)$, «Yo us tornaré lo real castellà a vós» $(818,8)$, «Teniuvos. No us tindreu» $(873,5)$, i en posició enclítica darrere vocal: «plàciaus condemnar aquell» $(126,4)$. En un parell de casos, darrere de vocal, apareix reduït a la forma asil.làbica s: «y voleu desonrrar a qui no*s deu res» $(883,2)$, «Ara hojats que.s fan a saber» $(118,21)$. En una ocasió es documenta la variant os: «y que hos havien vist» $(883,2)$.

Igualment, en el context intervocàlic $(\mathrm{V}-\mathrm{V})$ les formes asillàbiques $s, l, m, n$ es troben trenta vegades darrere els mots gramaticals que, què, $q u i, i(y, b i), e(1 \mathrm{cas})$, no, i tan sols en tres ocasions es documenta la forma $s$ en altres contextos, un dels quals és la conjunció perquè, composta també amb que: «ella, relant e testimoni, s'és confessada» $(62,6)$, «perquè s'era apartat de aquella» $(132,13)$, «aquella s'enprenyà» $(258,10 \mathrm{v}) .{ }^{11}$

Concloem, per tant, que, com en altres textos valencians dels segles XVI i XVII (cf. MARTí: 1994, 127-137; CANO: 1995, 55-69), en la formació de les formes asil-làbiques dels pronoms febles influí fonamentalment el context vocàlic precedent, sobretot els mots monosíl.labs de caràcter gramatical.

Les formes reforçades, formades a partir de les asilllàbiques, encara eren poc habituals al segle XVI. En els processos estudiats només n'hi ha un cas, en concret de la forma es: «en companyia de son criat, qui es no-

\footnotetext{
${ }^{10}$ En el context V-C la forma plena se es troba 24 vegades darrere d'un mot polisíl.lab, i tan sols una darrere de si: «si se jahia» $(258,1 \mathrm{v})$, i una darrere de la conjunció que: «que se són a $[b]$ sentats» $(213,27)$, seguida d'un verb començat per s, que no afavoreix, per tant, la forma asillàbica s.

${ }^{11}$ Un comportament similar té el pronom plural los, que presenta la forma reduïda 's darrere els monosílllabs $i$ ( $y$, hi), que, què, no, yo, ya (1 cas).
} 
mena Beltran Navarro» $(92,6)$, la qual, com veiem, es troba en un context on la pròtesi de la e es veu afavorida pel diftong [je].

En les combinacions pronominals del pronom datiu $b i(<l i) \mathrm{amb}$ els pronoms descendents del llatí ILLU es manté l'ordre CD + CI, habitual a l'època, ex. «que li donàs hun home que.s matàs ab ell, que si no lo $y$ donava de ací al diumenge, que ell li levaria la cara» $(883,5)$, «dix que [...] per la roba, que ell la y donaria» $(62,28)$. Quan es tracta del pronom neutre, aquest adopta la forma lo: «y quell lo y provaria» $(883,2)$.

També es conserva l'ordre CD + CI en les combinacions proclítiques lo vos i la us: «Bé stà, que yo lo vos pagaré» $(818,8)$, «Calau, señora, que algú la us tornarà, que la dita capa no*s perdrà» $(92,12)$. Però en posició enclítica s'inverteix, 's-lo, amb la forma asillàbica s resultant de la reducció del pronom en contacte amb la semivocal [w]: «Veus así hun real castellà, partiu's-lo los dos» $(818,9)$.

El pronom de CD també precedeix els altres en les combinacions ternàries $l$ sén i la se'n: "Y en açò, vingueren huns companyons del dit home $y \cdot l$ se'n portaren» $(819,6)$, «Y aprés la se'n portaren a sa casa» (62, 14).

Quant a la posició dels pronoms respecte al verb, es posposen sempre amb el verb en infinitiu, gerundi i imperatiu, com en la llengua actual. Amb la resta de temps i modes verbals solen ocupar la posició proclítica. Tanmateix encara es conserven casos d'ús enclític, com els que es donaven, amb major abundància, en la llengua medieval (cf. Coromines, 1983: 274-275; GHLC, 239-240). Això ocorre sobretot, encara que no sempre, quan el verb és la primera paraula de l'oració (3 casos) i més encara si aquest va precedit d'una conjunció copulativa (11 casos), ex. «E (Y) axí és ver e mostra's per lo que seguex (segueix)» (62, 19; 258, 7r; $269,2)$, «prengué a la dita chica y portà-la a casa del barber» $(845,5)$, «Y com ell, dit testimoni, no li volgués donar sinó sis diners, vingueren-se a barallar la dita Ventura y ell» $(819,1)$, «Y com fonch en lo carreró, jurà per la ànima de tal, jurant de Déu, «Ha-y ningun puto que parle per ell? 
Hixca ací» $(818,4) .{ }^{12}$ Només en una ocasió apareix en posició enclítica, en un verb que no està en infinitiu, gerundi ni imperatiu, quan aquest no és la primera paraula de la frase ni va darrere de la conjunció copulativa: «la muller del dit Joan de Bielça féu-se’n a una finestra» $(845,5)$.

\section{POSSESSIUS}

\subsection{EL POSSESSIU DE TERCERA PERSONA}

En alguns dels processos estudiats apareix el possessiu llur (lur), sempre en masculí singular, sense article i en posició prenominal, referit generalment a un posseïdor singular. ${ }^{13}$ En alguns documents només es troba en fórmules jurídiques ( 3 casos), o en la part de les diligències notarials (2 casos). Així, té caràcter formulístic en la presentació formal dels clams escrits: «en tota aquella millor via, forma e manera que a llur intent e propòsit aplicar puixa e deja» $(55,1)$, «en tota aquella millor via, forma e manera que a lur intent e prepòsit applicar-se puixa e deja» $(132,11)$, «en tota aquella millor via, forma e manera que a lur intent aplicar-se pot y deu» $(269,1)$. En el ms. 258 té un major ús, i apareix nou vegades en el clam escrit, en estil indirecte, ex. «y en servey de aquell, en llur casa és

\footnotetext{
${ }^{12}$ L'alternança que es dona en text següent en estil directe entre te'n vas i vas-te'n en un context similar i en boca del mateix parlant, deu reflectir la vacillació de la llengua parlada del moment: «E dix a l'hu de aquells: "Per què has dexat la faena y te'n vas?" [...] “Com dexes-me la pasta en la pastera y vas-te'n?" » $(873,1)$.

${ }^{13}$ Només en una ocasió es documenta amb un posseïdor plural: «si no y seran en lur contumàcia, seran rebuts» $(92,28)$. L'ús de llur referit a un sol posseïdor, encara que rarament, es troba al segle XV. Coromines (DECat, V, 310) afirma que la major part de casos medievals que s'han al.legat «són de textos mal publicats», però afirma «que potser sén trobi algun d'autèntic entre valencians populars del segle XV», i en cita un exemple de sant Vicent Ferrer. També el llegim en el Regiment de la cosa pública (València, 1499) d'Eiximenis: «Molt savis, honorables e reverents senyors [...], jurats de València, frare Francesch Eximéneç, de l'orde dels frares menors, lur humil servidor en Jesuchrist» (p. 3). S'incrementa al segle XVI (FARRENY: 2004, 243; BARBERÀ I IBIZA: 2018, 289). Aquest ús es podria explicar per ultracorrecció dels escrivans (SARAGOSSÀ: 2000, 258), encara que també cabria la possibilitat que obeís a un ús vacil.lant de la llengua, sobretot en un moment de decadència. Tinguem en compte que així com hom usava seu i son per a un posseïdor singular i plural, per confusió alguns usuaris de la llengua podrien haver fer el mateix amb llur, almenys en l'escriptura.
} 
estada e vista estar» (1v), «a hon tingué excés carnal ab la dita Catherina Matheu[a], llur criada» (2r). Només en una ocasió es troba llur en un clam oral, també en estil indirecte, però en aquest cas l'escrivà el va cancel.lar i el substituí per la forma feble son, possiblement perquè fou la que realment digué la denunciant: «E aprés de acò, aquella anà a cercar son (cancel.lat «a llur») marit hi.l féu venir per a que pegàs a ella, clamant» $(213,2){ }^{14}$

\subsection{ELS POSSESSIUS FEMENINS}

En els processos estudiats les formes plenes femenines dels possessius són sempre les etimològiques, i no apareixen encara les analògiques corresponents. Es troben en tots els contextos, des dels més formals, com poden ser algunes fórmules jurídiques, fins a les declaracions verbals dels testimonis, en estil indirecte i també en estil directe, més pròxim a l'oralitat. Donades les característiques dels textos, la més emprada és sua, i en un cas, en estil directe, apareix mia, ex. «estant ell, testimoni, a la sua porta» $(213,15)$, «y dix: "Per la ànima de tal", jurant de Déu, que partiria la dita capa, puix que era sua» $(818,7)$, «veu que una dona nomenada Ventura cridava dins la sua cambra grans crits» $(819,8)$, «Sellavors, lo dit Francés Pons dix: "Donar-la-he la mia part a mon pare, puix és parçoner, y yo faré la fahena”» $(818,7)$.

Les formes meua, teua, seua, que són rebutjades com a vulgarismes en les Regles d'esquivar vocables del segle XV, segons Coromines (DECat, VII, 883), guanyaren «terreny lentament en la llengua parlada i molt poc en la llengua literària» i segons Batlle et al. (GHLC, 247-248), «durant l'edat moderna s'estendran progressivament». De fet, en els textos dels

${ }^{14}$ Generalment hom considera que llur «anà caient en desús durant l'edat moderna» (GHLC, 250-251), i diversos autors pensen que possiblement, almenys en valencià i en català nord-occidental, al segle XVI era ja una forma en desús o un arcaisme (SCHMID: 1988, 77; FARRENY: 2004, 243; GIRALT: 2012, 68). Si bé, donada la presència, encara que escassa i només en estil indirecte, en alguns processos judicials del segle XVI, Barberà i Ibiza (2018, 289-291) afirma que «no cal descartar que [...] l'ús de llur encara romanés viu» en algunes construccions. Per la seua part, Rabella $(1998,247)$ pensa que «el fet que no aparegui en les declaracions directes» dels processos fa pensar que no es fes servir en la parla popular. 
segles XVI i XVII encara es preferien clarament les formes etimològiques mia, tua, sua (i els plurals corresponents) (cf. MARTI: 1994, 150; CANO: 1995, 78-79; FARRENY: 2004, 241-242; GIRALT: 2012, 68; BARBERA I IBIZA: 2018, 286). Aquest fet, juntament amb la presència no únicament en textos formals, sinó també en altres més planers o més pròxims a l'oralitat, pot fer pensar que, almenys al segle XVI, encara devien tenir alguna presència en la llengua parlada.

\subsection{POSSESSIUS ÀTONS}

En la llengua antiga les formes reduïdes dels possessius s'empraven correntment en posició prenominal (cf. BADIA I MARGARIT, 1981: 307; MOLL, 2006: 179), si bé en aquesta posició ja experimentaven la concurrència de les formes plenes (cf. DUARTE \& ALSINA: 1986, 78). Com en altres textos de l'època, ${ }^{15}$ en els processos consultats els possessius àtons (354 casos, 90'1\%) són molt més usats en aquesta posició que els corresponents tònics (39 casos, ${ }^{16}$ 9'9 \%), i no únicament amb noms de parentiu, i altres com casa o vida, on encara s'usen actualment en valencià, sinó en general, ex. «son procurador» $(92,21)$, «son mestre» $(876,3)$, «sa segona contumàcia» $(118,19)$, «sa capa» $(883,5)$, «sos peccats» $(62,6)$, «ses orelles» $(132,4)$.

\section{DEMOSTRATIUS}

\subsection{FORMES REFORÇADES I NO REFORÇADES}

Com és habitual en els textos valencians del segle XVI, ${ }^{17}$ predominen els demostratius no reforçats (18 casos, $78^{\prime} 2 \%$ ) sobre els reforçats ( 5 casos, 21 '7 \%). Ara bé, s'observa un millor manteniment dels demostratius reforçats en la forma de masculí singular aquest, de manera que en els processos estudiats hi ha dos casos d'aquesta forma i cap de la no reforçada equivalent. En aquest fet, que es repeteix en altres textos valencians

\footnotetext{
${ }^{15}$ Veg. Martí (1994, 150), Farreny $(2004,242)$, Callado et al. $(2018,56)$ i Giralt $(2012$, 69), si bé el darrer només es refereix al predomini dels possessius àtons davant noms de parentiu.

${ }^{16}$ A més, nou d'aquests casos formen part de fórmules jurídiques repetitives.

${ }^{17}$ Casanova $(1993,176)$ afirma que «l'estigmatització d'aquest davant est» té lloc «a partir de la segona part del XV i sobretot del XVI».
} 
de l'època, probablement intervingueren factors fonètics i morfològics (veg. MARTÍ: 1994, 145; MARTí: 2012, 619; MARTÍ \& SERRA: 2009, 112; CALLADO et al.: 2018, 55). D'altra banda, la presència de quatre casos de demostratius no reforçats en els fragments en estil directe confirma la seu popularitat en el valencià de l'època, ex. «Y com fonch a la porta, comencà a dir: "Estes putes, bagasses, yo les castiga[ré]"》 $(213,17)$, «a crits dix a la porta d'ella, testimoni [...]: "Esta bagassa merexeria entrar dins sa casa y levar-li lo nas de la cara y dar-li de bastonades"» $(883,3)$, si bé les formes reforçades no hi són absents tampoc de l'estil directe (un cas): «y lo dit Roca digué al dit Miquel Angulo: "Veu aquell home qu·està allí? Un dia de aquestos li pegaré, y vós sereu ab mi”» $(92,10)$.

\subsection{ELS DEMOSTRATIUS ADVERBIALS}

En els processos estudiats hi ha deu casos del demostratiu ací, usat sempre amb valor díctic, ex. «Na bagassa, mala dona, jo us mataré ací en lo carrer!» $(126,3)$, «Ha-y ningun puto que parle per ell? Hixca aci»» $(818,4)$. També pot adquirir una projecció temporal, sense perdre el valor díctic, per relació al temps de l'enunciació, en l'expressió d'ací a + substantiu temporal: «Bagassa, mira que de aci al diumenge me has de donar hun home qués mate $\mathrm{ab} \mathrm{mi}$, si no yo pujaré en ta casa y te levaré la cara» $(883,3)$.

L'adverbi aquí, menys usat (4 casos), es troba tant amb valor díctic com anafòric. Té valor díctic en «Digau, à-y ningun home aquí que faça bo que yo y ma muller havem dit que Saura li feya a na Miquela en casa de Sans?» $(883,2)$, i en l'expressió anar-se'n per aquí avant, amb el sentit de desfer-se d'algú, despatxar-lo virulentament: «E vent-lo ell, dit testimoni, ajuntà $\mathrm{ab}$ aquell, y li dix que tingués al rey. E aquell li dix que se n'anàs per aquí avant. E ell, dit testimoni, dix que-s tingués al rey y que què volia dir que se n'anàs per aquí avant. E lo dit Ros li respongué: "Tira, bujarró! ¿Con quién piensas hablar?”» $(118,8)$, i sembla tenir valor anafòric en: «y ell, dit clamant, dix al dit Anthon Serrano, stant a la porta d'ell, dit clamant, aqui stant Joan Matoses, que és companyó de clavari, que li donava recapte» $(818,6)$. Tot i que menys usat que ací, l'ús en fragments en estil directe $\mathrm{i}$ en declaracions orals en estil indirecte indicaria que a la 
segona meitat del segle XVI aquí no era desconegut en valencià central, i que podia ser usat amb valor anaforic i díctic. ${ }^{18}$

En dues ocasions, en fragments en estil directe, es documenta l'adverbi ahí (aý), amb valor díctic de segona persona: «vingué lo dit Sancho Navarro y, pujant per la scala, dix a una neta d'ella, clamant: "Digues, està aý ta major?"» $(213,3)$, «E lo dit Sancho Navarro alçà lo cap e li dix: "Per cap de tal! [...] Na vil, bagassa, si munte aý, yo te cremaré la ca[s]a”» (id., 12). ${ }^{19}$

\subsection{El DEMOSTRATIU TAL ${ }^{20}$}

La forma tal funciona com a pronom i com a determinant davant d'un nom, ex. «com tals crims e delictes» $(55,3)$, «ni ha hoyt dir tal cosa fins ara» $(62,25)$, «són verguetes de la Real Alguazeria, y per tal són tenguts» $(118,15)$, «reptant que no digués tal» $(883,11)$. En diverses ocasions forma l'expressió tals e (o) semblants + nom, ex. «e han acostumat de fer tals e semblants delictes» $(55,3)$, «dient-li tals o semblants paraules» $(213,25)$.

Veiem que generalment tal adopta flexió de nombre però no de gènere. Tanmateix, sí que adopta el gènere femení en l'expressió despectiva ser una tala $i$ quala, que apareix dues vegades en un mateix procés, tant en estil indirecte com directe: «En açò, la dita na Vidala scomencà de desenfrenar contra ella, testimoni, dient que era una tala y quala, desonrrant-la de bagassa públicament» $(883,1)$, «e li dix: "Señora Ferràndiza, gran enuig porte, que é passat a casa de na Miquela, a demanar-li los peus de ferro, y me ha desonrrat ma filla, que té mala lengua y qu+és una tala y quala"» (id., 2). ${ }^{21}$ Aquesta expressió la trobem encara en textos po-

\footnotetext{
${ }^{18}$ Sobre l'evolució d'aquí en valencià, vegeu Casanova $(1993,177)$, el qual afirma que mantingué «el seu valor anafòric i deíctic de 2 n grau fins almenys mitjan XVII, però en continu desús».

${ }^{19}$ Sobre el naixement d'ahí en valencià, al segle XVI, vegeu Casanova (1993, 178-179).

${ }^{20}$ Sobre el caràcter demostratiu de tal, vegeu la GLC (p. 607).

${ }^{21}$ En el DCVB es diu que «dialectalment i en la llengua antiga» es troba la forma tala, i sén citen exemples d'Ausiàs March, de Jaume Roig i del Tirant. En el DAg (VIII, 12) sén citen també exemples més tardans, fins al Rector de Vallfogona. Segons Coromines
} 
pularistes valencians del segle XIX: «si la estachera de dalt / és una tala, una quala» (El fadrí, Biblioteca Municipal de València, ms. 7116), «M’à dit queres una tala / y una cuala; un escachet, / y que.t busca» (Constantí Llombart, Tipos d'auca, València, 1878, p. 133).

Es tracta d'una expressió, encara que despectiva, amb un cert to eufemístic. Com eufemístic és també l'ús de tal en renecs: Cap de tal $(62,6)$, per cap de tal $(218,12)$, per la ànima de tal $(118,8)$, per lo fetge de tal $(818$, $2)$, per lo cul de tal $(818,4)$. Sovint l'escrivà aclareix que tal és la manera d'encobrir les paraules de la persona citada, que realment jurà per Déu: «lo dix Francés Pons dix: "Per la ànima y per lo fetge de tal", jurant de Déu» $(818,2)$.

També juntament amb qual, però de caràcter diferent, és l'expressió per tal qual se conté (té dit), ex. «té a la dita Speransa Lombart y de Xea per tal qual se conté en lo dit capítol» $(269,7)$, «Y dix que no.ls té per tals quals se conté en lo dit capítol» (id., 9), «per tenir-lo per tal qual té dit dessús, no.l deixa dormir en la enfermeria» $(847,2){ }^{22}$

Per últim, forma les construccions consecutives de tal manera que $(118,16 ; 180,4)$ i de manera tal que $(258,6)$, i la locució final per tal que $(213,26)$.

\section{QUANTIFICADORS}

No s'intercala la preposició de entre el quantitatiu molt i el substantiu: «y té molt conte en sa casa y faena» $(92,9)$. En el cas de tant, davant d'un nom masculí, documentem tres casos amb preposició i un sense, amb el mateix substantiu, fins i tot en el mateix text, cosa que indicaria una vacil.lació a l'època: «Y lo dit Joan de Bielça respongué que no li havien fet tant de mal per avalotar tant. Y la dita chica respongué que tant

(DECat, VIII, 215), la forma femenina tala es troba en obres del segle XV, «sobretot (o només) valencianes», i crida l'atenció sobre els casos en què forma parella amb quala, «que resta més viu, i és també castellà».

${ }^{22}$ Cf. «jo la tinch / per tala quala en lo article la pinten» (FARRENY: 2004, 259). 
mal vingués per sa casa com ella tenia, perquè ella no podia servir $[\mathrm{a}] \mathrm{m}[\mathrm{o}] \gg(845,5){ }^{23}$

Com era normal en català antic, és habitual l'ús de l'indefinit algun, $a$ amb valor negatiu, quantificant un nom. Tot $\mathrm{i}$ tenir el mateix valor que ningun (nengun), a en els processos ocupen posicions diferents, ja que el primer apareix darrere el nom, i el segon ocupa la posició d'especificador, ex. «sens recel algun» $(62,21)$, «ni maleficis alguns» $(261,3)$, «sens dany ni perjuhí de persona alguna» $(269,2)$, «ni ningun altre mal accident» $(62,35)$, «no y ha nengun home» $(818,2),{ }^{24}$ «a ninguna persona» (883, 8). En una ocasió apareix algú quantificant un nom, també amb valor negatiu i posposat: "per hara no entén posar clam algú» $(873,4){ }^{25}$

Quan algun, a té valor positiu precedeix el nom, ex. «armats per algunes parts» $(62,19)$, «per intervenció de algunes persones» $(126,7)$. Només en una ocasió, en una oració interrogativa indirecta (context hipotètic), apareix posposat: «Fonch interrogat que diga si sab que hun home que en la present hora ha vist nafrat en casa del magnífich micer Bas havia tengut diferències algunes ab alguna dona del dit partit» (819, 4).

Com hem vist, ningun és habitualment negatiu, però en dos casos, en oracions interrogatives, té caràcter positiu: «Ha-y ningun puto que parle per ell? Hixca açí» $(818,3)$, «Digau, à-y ningun home aquí que faça bo que yo y ma muller havem dit que Saura li feya a na Miquela en casa de Sans?» $(883,2)$. L'ús en fragments en estil directe sembla apuntar a la pervivència oral d'aquest ús en el valencià del segle XVI.

Com ocorre sovint en la llengua antiga, en construccions partitives s'usen les formes algú i ningú (nengú): «si algú o alguns del dit offici»

\footnotetext{
${ }^{23}$ Les dades dels nostres processos, com la d'altres textos valencians antics (cf. MARTÍ: 1994, 172; ESCARTÍ \& RIBERA: 2019, 109-110), indiquen que aquesta preposició no estava tan estesa amb alguns quantificadors com ocorre actualment en valencià general davant un nom masculí singular (cf. BELTRAN \& SEGURA: 2017, 202-203).

${ }^{24}$ Predominen clarament les formes amb $i$, i només documentem dos casos de les formes més antigues amb e (NEC UNU), aquesta i un cas de nengú (269, 2).

${ }^{25}$ Aquest ús adjectival d'algú es documenta des de la llengua medieval, i, segons Farreny (1986: 153), es tracta d'una pèrdua de la $-n$ final per enclisi.
} 
$(818,5)$, «no.n coneix ningú dels altres» $(819,5)$, «ni a nengú de sos vehins» $(269,2)$.

Com en altres textos de l'època, hom fa servir habitualment els indefinits cascun, cascú (22 casos), i només en una ocasió apareix cada u. D'altra banda, com hem vist amb algú i ningú, en construccions partitives es fa servir cascú (i cada u) de: «donem-li cascú dels dos que restarà hun real castellà per home» $(818,8)$, «cada bu de aquells per si» $(269,4)$.

L'indefinit qualsevol es manté invariable en plural, ex. «contra qualsevol altres còmplices» $(62,17)$, «contra qualsevol altres factors» $(92,8)$.

\section{RELATIUS}

En les oracions subordinades de relatiu amb antecedent i sense preposició hom fa servir normalment el relatiu que, i en les explicatives també el relatiu compost article + qual. Però en les oracions de relatiu explicatives amb antecedent de persona, amb funció de subjecte, s'utilitza sovint el relatiu qui, si bé, amb poques excepcions, restringit a determinades estructures pròpies del llenguatge notarial, on deu conservar-se aquest pronom per tradició: per al jurament: «qui jura» $(62,7 ; 92,4 ; 118$, 2; etc.), per assenyalar l'adreça: «qui està a» (62, 2; 213, 2; etc.) o «qui està en» $(92,2 ; 118,4 ; 132,2$; etc.), i per indicar l'edat: «qui dix tenir... anys» $(213,9,11 ; 876,3$; etc.), «qui dix ésser de edat de» $(818,1,3 ; 819$, 1 ; etc.).

També s'empra habitualment el relatiu qui en l'expressió del llenguatge jurídic i administratiu qui dessús, referida a testimonis, delats o denunciats citats anteriorment, i que s'ajusta a la voluntat de precisió d'aquest tipus de llenguatge, ex. «al dit Pere Millà, velluter, delat qui dessús» (62, 32), «lo dit en Pere Novella, delat y denunciat qui desús» (92, 10), «la dita Catherina Poses, delada e denunciada qui desús» $(213,24)$. Cal relacionar-la amb la construcció llatina del llenguatge jurídic testes qui suppra (proxime nominantur, nominatur o nominati), que es llegeix també en alguns dels processos consultats.

Fora d'aquests contextos, és molt poc usat el relatiu qui en les oracions amb antecedent explícit, i quan apareix ho fa en oracions explicatives amb antecedent personal $\mathrm{i}$ amb funció de subjecte: «e mestre Johan 
Brin, cirurgià, qui curà a la dita portoguesa nafrada» $(62,35)$, «com Penarroja lo baxet, qui pledeja ab lo señor de Callosa» $(876,4)$, «Fonch atrobada per lo alguazil Rafel Moragrega, qui accedí de provisió del molt magnífich Miquel Àngel de Bas» $(883,1)$.

En un cas, en una oració especificativa, l'antecedent és l'indefinit $u$ : «encontraren $\mathrm{ab}$ hu qui.s diu e nomena Joan Ros, lo instador» $(118,12)$.

En les anomenades oracions de relatiu semilliures, ${ }^{26}$ només documentem el pronom qui en tres ocasions, precedit de l'article definit: «e són encorreguts en totes les penes que los qui rompen pau y treua encorren» $(55,3)$, «al temps que.s partix lo cuyram, se acostuma de pendre en jurament lo qui.l pren de hu en hu per lo majoral» $(818,5)$, «li respós que [...] li pegaria al dit Penarroja de bastonades y al qui parlàs per ell» (876, 5).

En les oracions de relatiu amb antecedent, darrere de preposició, és molt més utilitzat el relatiu compost article + qual que no els pronoms què (3 casos) i qui ( 1 cas), ex. «que la dita supplicatió e criminal acusatió no posava per vexar ne molestar les persones contra qui la posava» (92, 16), «sien aquells condemnats, oprimits e castigats en totes aquelles penes, axí corpora[1]s com pecuniàries, en què han encorregut, etc» (213, 26), «E axí és ver e consta ab lo acte de la dita pau y treua, del qual fa fe» $(55,2)$, «les quals mana ésser posades e insertades en procés, de les quals ne atorga còpia e trellat a cascuna de les dites parts» $(92,27)$, en el darrer cas amb pleonasme pronominal.

No és molt habitual en els processos consultats la tendència col-loquial a la construcció analítica amb el relatiu que, reduït en la pràctica a un mer nexe, i on el pronom feble fa les funcions sintàtica i anafòrica, però en trobem algun cas: «en hun cabàs, huns canons de seda de pèl, que $y$ pot haver obra de mij.alneta de seda verda» $(62,2)$.

El relatiu compost darrere de la preposició de pot funcionar com a complement del nom; se situa darrere del nom, ex. «y en companyia de hun jove lo nom del qual aquell ignora» $(92,4)$, «a la voluntat del qual lo dit Lorens Sanctjoan aderí» (258, 7r), pot haver-hi repetició de

${ }^{26}$ Sobre aquestes oracions, vegeu la GLC (p. 1035, 1048-1052). 
l'antecedent: «parlant ell, testimoni, ab la dita Cathalina en hun carreró del carrer de Sant Vicent, lo nom del qual dit carreró no sab ell, dit testimoni» $(132,5)$.

Quan l'antecedent és oracional, l'oració de relatiu va encapçalada amb els sintagmes (de, per) les quals coses $(92,3,17,19,21 ; 132,16 ; 811$, 2; 821, 2), per la qual causa $(92,11)$ i per la qual raó $(62,9,22)$, i només en una ocasió es documenta per lo qual $(92,11)$.

En les oracions de relatiu semilliures per a designar entitats no animades generalment es fa servir la construcció amb el relatiu que precedit de l'article lo, ex. «E dix que nega lo que ha negat y atorga lo que ha atorgat» $(62,31)$, «yo stimaria més tenir lo que vos deuen que no lo que teniu» $(818,7)$. Només en una ocasió es documenta allo que: «lo qual dix a ell, dit relant, que miràs lo que manava, y que en allò que feya se amoderàs» $(118,4)$.

\section{VERBS}

\subsection{PRESENT D'INDICATIU, PRESENT DE SUBJUNTIU I IMPERATIU}

La primera persona del present d'indicatiu de fer és la clàssica faç (< FACIO) (62, 41), conservada en balear i valencià (DCVB). Les desinències de les persones primera i segona del plural dels verbs de la primera conjugació són les etimològiques -am, -au, respectivament: cercam $(62,30)$, cuitau $(818,7)$, restau $(818,7)$, i el mateix ocorre en la segona persona del plural de l'imperatiu: anau $(62,29 ; 818,7)$, callau (92, 12), deixau (818, 9), digau $(883,2)$, entrau $(883,9)$, mirau $(818,6)$, pagau $(818,7,8)$, pujau $(883,9)$, vingau $(62,29)$.

En present de subjuntiu, en el verb ser, es mantenen les formes clàssiques sense increment velar, sia $(55,4 ; 92,30$; etc.), sien $(62,24 ; 92$, 15; etc.); igualment en voler, vulla (< VOLEAT) $(62,6 ; 132,27)$, en el verb plaure, plàcia (< PLACEAT) $(62,38 ; 118,18 ; 126,4)$, en deure prevalen clarament les formes deja (<DEBEAT) $(55,1 ; 62,38 ; 122,2$; 132, 11), degen (dejen, dexen) (< DEBEANT) $(55,3 ; 62,23 ; 126,4$; 
etc.), per un únic cas de la velaritzada deguen $(92,15) .{ }^{27}$ En el present de subjuntiu del verb poder es mantenen les formes antigues puixa (< ${ }^{*}$ PÓSSIAT) (55, 1; 92, 29; 126, 6; etc.) (10 casos), puixen (< *PŎSSIANT) $(258,4 \mathrm{r}, 10 \mathrm{r}$ ) (2 casos), juntament amb la velaritzada puga $(55,1 ; 92,8 ; 132,23 ; 258,1 \mathrm{r})$, menys utilitzada $\left(4\right.$ casos) ${ }^{28}$ El present de subjuntiu de morir és el clàssic muyra (< $\left.{ }^{*} \operatorname{MORIAT}\right)(55,3)$, conservat en baleàric i en part del valencià (MOLL, 2006: 189).

En una ocasió es documenta la forma de tercera persona ixque, en un fragment en estil directe: «Hixque algun belitre que parle per lo majoral, fill de hun tramuçer» $(818,9)$, si bé més avant, en boca del mateix personatge, es fa servir hixca: «cridant grans crits: "Hixca lo puto majoral de la casa o qui parle per ell”» $(818,10)$. Això podria ser indici encara d'una certa vacillació en la llengua oral en la desinència de la tercera persona -a / - e (<-AT) en valencià central, sobretot si el context fonètic era favorable, ${ }^{29}$ però amb tendència clara a imposar-se la forma més prestigiosa -a, si més no en la llengua escrita (cf. CASANOVA: 1989, 347; MARTí: 2012, 563; WHEELER: 2012, 897, 905).

Pel que fa als verbs incoatius de la tercera conjugació, en el present d'indicatiu predomina clarament l'increment -eix (-ex) (31 casos, 88'57\%) sobre -ix (4 casos, 11'42\%): «aboleix» $(126,6)$, «aboleixen» $(62,40)$, «constituexen» $(92,28)$, «desisteix» $(126,6)$, «desesteixen» $(62,40)$, «posseheix» (261, 3), «prosseheixen» $(55,3)$, «proseheixen» (92, 15; $258,3 \mathrm{r}, 8 \mathrm{v})$, «procehexen» $(62,23 ; 126,3 ; 180,4)$, «proceheixen» $(118$, $18 ; 132,14$; etc.), «regeix» $(819,6)$, «requereixen» $(883,4)$, «segueix» $(118,8 ; 258,4 r$, etc $)$, «seguex» $(62,19 ; 269,2)$; «abollix» $(213,8)$, «partix» $(818,5)$, «procehixen» $(147,4)$, «servix» $(180,2)$.

En el present de subjuntiu totes les formes incoatives, de tercera persona del singular, contenen la e com a vocal de l'increment incoatiu: «proceheixca» $(62,38)$, «produheixca» $(132,22)$, «succehesca» $(62,23)$,

\footnotetext{
${ }^{27}$ Les tres formes (deja, degen, deguen) es troben en les diligències notarials, formant part de fórmules juridicoadministratives.

${ }^{28}$ Totes tres es documenten en diligències notarials, sovint formant part de fórmules juridicoadministratives.

${ }^{29}$ En ixque la vocal desinencial està pròxima a la vocal i la consonant palatals del lexema.
} 
«succeheixca» $(55,4 ; 126,4 ; 132,15 ; 213,26)$, «succeheixa» $(92,15)$. La majoria de casos estan formats amb l'increment palatalitzat -eixc, el qual segurament s'explica per analogia amb les formes palatals incoatives del present d'indicatiu amb -eix (cf. Casanova, 1993: 306-307; GHLC, 369). Notem també la forma «succeheixa», sense la consonant velar pròpia dels incoatius en subjuntiu, que apareix en una ocasió, i que deu explicar-se també per analogia de les formes de l'indicatiu. ${ }^{30}$

Així, doncs, comprovem que en els processos estudiats en l'increment dels verbs incoatius de la tercera conjugació encara predomina clarament la vocal $e$, i que en el present de subjuntiu està ja molt estesa la solució híbrida -eixc. Si comparem aquests resultats amb els d'altres textos valencians del segle XVI, que mostren diferències quant al predomini dels incoatius amb e o amb $i$ (cf. MARTí: 1992, 59-60; MARTí: 1994, 184-185; MARTí \& SERRA: 2009, 126; CALLADO et al.: 2018, 35; BARBERÀ I IBIZA: 2018, 320-321, 336), arribaríem a la conclusió que en el valencià de l'època, almenys en la llengua escrita, depenent del text i de l'autor, hi havia bastant variació en aquest punt, però que en el subjuntiu, independentment de la vocal de l'increment incoatiu (e o $i$ ), prevalien clarament les formes palatalitzades. ${ }^{31}$

D'altra banda, el verb referir manté la forma no incoativa antiga refir $(92,3)$.

\subsection{IMPERFET D'INDICATIU}

A conseqüència de la caiguda de la - B- desinencial, en alguns verbs de la segona conjugació es formaren en català uns imperfets d'indicatiu amb hiatus. Més tard, excepte en valencià general, ${ }^{32}$ en les formes amb el

\footnotetext{
${ }^{30}$ Aquestes formes incoatives de subjuntiu sense consonant velar es poden trobar també en altres textos valencians dels segles XVI i XVII, per ex. «repartexen», «concedexa» (1558) (MARTÍ: 1992, 59), «cumplixen» (1673) (MARTí: 1991, 71).

${ }^{31}$ Segons Casanova $(1993,308)$ i la GHLC (p. 366-367), el procés de substitució de la $e$ de les formes incoatives per $i$ en català occidental (incloent-hi el valencià) s'inicià al segle XIV i s'estengué progressivament entre els segles XVI i XVIII, primerament en la llengua oral i després en l'escrita.

${ }^{32}$ En valencià també es coneixen unes formes amb el vocalisme simplificat, tipus dia, ria, fea, vea (cf. PÉREZ SALDANYA: 1998, 193), que no apareixen en els processos estudiats.
} 
radical acabat en vocal, es va produir un desplaçament de l'accent a la vocal del radical per tal de desfer el hiatus i possiblement també per la pressió analògica exercida pels infinitius rizotònics (cf. PÉREZ SALDANYA: 1998, 192-193; GHLC, 360).

Coromines $(1983,270)$ diu que «l'accentuació dêia ja es troba a finals de l'Edat Mitjana», i Pérez Saldanya $(1998,192)$, «tenint en compte que les formes amb $b$ són generals en Llull [...] i les formes amb y en $U n$ llibre de cort reial mallorqui del segle XIV», conclou que «el canvi ja s'hauria consumat, almenys en una part important del català, a mitjan segle XIV». Però no sempre resulten igual de clarificadores les grafies $y$ i bi. Per exemple, Par (1928: 30-31) troba que en el Curial apareix tant debia com deya, jabia com jaya, etc., i creu que «segurament jahia, jaya són dos grafemes del mateix fonema» amb la $i$ vocal plena. La fluctuació gràfica en aquests imperfets es troba també en altres textos medievals (cf. COLÓN \& GARCIA: 1987, 111; RABELLA: 1998, 234; DiÉGUEZ: 2001, 226; AlEGRE: 2007, 162-163), i en dificulta la interpretació fonètica.

En els nostres processos, com en altres textos de l'època, hi ha també fluctuacions gràfiques en aquests casos. En posició interior de paraula darrere de vocal la grafia $h$ seguida de $i$ indica sempre un hiat, ex. «agrahit» $(62,29)$, «constituhia» $(92,20)$, «provehit» $(118,18)$, «vehinat» $(126,2)$, «statuhides» $(269,4)$. Per la seua part, la $y$ en molts casos assenyala un diftong, ex. «perayre» $(126,1)$, «huyt» $(258,5 r)$, «cayguda» $(213,17)$, «cuyram» $(818,5)$, però en ocasions també representa un hiat, i això té lloc especialment en determinats mots, possiblement per tradició: les formes del verb oir, «hoÿt» $(126,3 ; 118,22)$, «hoynt» $(118,2)$, «hoÿda» $(132,14)$, «hoý» $(213,4 ; 819,8)$, «hoÿa» $(213,20),{ }^{33}$ en «traÿ-

Per a la situació dialectal del valencià, vegeu Beltran Calvo, Segura-Llopes (2017, 110, 220), els quals afirmen que en valencià central, si bé aquests verbs no han desplaçat generalment l'accent al radical, sí que s'ha produït el desplaçament en dur i fer, i que en valencià meridional són més freqüents les formes rizotòniques.

${ }^{33}$ Les formes del verb oir també es troben amb hi, fins i tot en un mateix procés: «hohit» $(118,22)$, «hohits» $(269,2)$, «hohida» $(269,3)$, «ohit» $(213,25)$, «hohiren» $(132,26)$, «ohien» $(132,26)$. 
dor» $(213,12,14,18)$ i en els noms propis «Loýs» $(180,1)$, «Loÿsa» (92, $1,8,16,20)$, «Luÿsa» $(92,8,9,18,30)$.

En els imperfets d'indicatiu dels verbs que ara ens ocupen apareix hi enः «dehia» $(62,9 ; 126,3)$, «dehien» $(62,10[2], 12)$, «vehia» $(118,5)$, «trahia» $(147,7)$, «jahia» $(258,1 v, 2 v),{ }^{34}$ que, com hem dit, en els processos consultats representa sempre un hiat. Encara que en el conjunt dels processos és majoritari l'ús de $y$ en l'imperfet d'indicatiu dels verbs dir i fer: «deya» $(92,23 ; 118,6,9,17 ; 132,4,6,7,8 ; 269,3 ; 819,4,5 ; 849,1$; $883,6,7,9)$, «deyen» $(118,6 ; 132,6 ; 213,12,14,17,20,22 ; 819,8$; $873 ; 876,3 ; 883,8,10)$, «deyeu» $(818,7)$, «feya» $(92,20 ; 118,4,6,7$, $13,17 ; 132,5 ; 841 ; 180,4 ; 213,4,16,25 ; 258,4 r ; 269,2,3 ; 813,2)$, no hem d'oblidar que molts dels processos on s'utilitza la grafia $y$ en aquests verbs la fan servir també en altres mots on clarament representa un hiat. ${ }^{35}$

\subsection{IMPERFET DE SUBJUNTIU, PLUSQUAMPERFET DE SUBJUNTIU I CONDICIONAL EN -RA}

En l'imperfet $i$ en el plusquamperfet de subjuntiu hom fa servir habitualment les formes verbals en -s (-às, -és, -is) procedents del plusquamperfet de subjuntiu llatí, ex. «li pregà la muller de aquell que la acompanyàs a casa de Tamayo» $(62,7)$, «com personalment no l'agués pogut trobar, per a que fos, vingués y comparegués davant lo magnífich relador de la present causa en la Real Audiència» $(118,21)$, «lo instà e comogué per a que accedís e anàs a la casa de la di[ta] Francina Gilabert» $(213,24)$, «y los digueren ques levassen de allí» $(876,5)$.

Les formes en -ra, que en llatí funcionaven com a plusquamperfets d'indicatiu, en català passaren a ser condicionals, i en valencià començaren a utilitzar-se com a subjuntius en la pròtasi de les condicionals en la

\footnotetext{
${ }^{34}$ En alguns d'aquests textos $(62,126$ i 147) no apareix mai $y$ en l'imperfet d'indicatiu d'aquests verbs, sinó només hi. En el primer en una ocasió apareix by: debyen $(62,13)$.

${ }^{35}$ Diversos filòlegs interpreten la grafia $y$ que apareix en aquest tipus d'imperfets en textos valencians dels segles XV, XVI i XVII com a vocal plena (cf. GARCIA SEMPERE: 2013, 71; CASTAÑO \& MAS: 2015, 66), però altres interpreten que formes verbals com veya i feya en textos valencians dels segles XVI i XVII representen formes rizotòniques (SCHMID: 1988, 99; CANO I IVORRA: 1997, 97; BARBERÀ I IBIZA: 2018, 323).
} 
segona meitat del segle XV (cf. RIDRUEJO: 1985; PÉREZ SALDANYA: 1998, 297-308; SEGURA-LLOPES: 2015, 23-27). En els processos estudiats apareixen tres vegades en oracions condicionals irreals de passat: «E hohí ell, testimoni, que lo dit jove nomenat Ros dix que si ell haguera tengut hun punyal, haguera pegat de punyalades al dit alguazir» $(118,8)$, «E hohí ell, dit testimoni, que lo dit Ros estava dient: "Si yo tinguera hun punyal, yo haguera pegat de punyalades a l'alguazir"» $(118,10)$, «E als crits que aquell cridava acudí alguna gent, e trobaren que lo dit suplicant stava nafrat de dita coltellada. E si no fora per lo auxili de Nostre Señor Déu e per la ajuda dels que acudiren als dits crits, lo dit delat haguera mort al dit suplicant» $(180,3)$. En les tres oracions el subjuntiu en -ra de la pròtasi (baguera tengut, tinguera i fora) marca anterioritat, potencialitat ja exhaurida, i correspon al plusquamperfet de subjuntiu. Al mateix temps, les formes verbals en -ra de l'apòdosi corresponen al condicional perfet.

L'ús dels condicionals en -ra en l'apòdosi de les oracions condicionals motivà que les formes en -ra s'estenguessen a la pròtasi, on adquiriren el valor de subjuntius, primer només per a marcar anterioritat, potencialitat ja exhaurida, i més tard també possibilitat vàlida per al present o el futur. ${ }^{36}$ Però amb aquest darrer valor no documentem encara aquestes formes en els nostres processos, les quals, com veiem, apareixen sobretot en oracions condicionals, encara que en un procés de 1567 trobem ja un plusquamperfet de subjuntiu en -ra en una oració no condicional: «E dix que lo dit Aguilar e molta gent del vehinat estaven y deyen que merexia lo dit flaquer que lo dit moço lo haguera mort» $(873,2)$.

\subsection{PERFET D'INDICATIU}

En alguns verbs es conserven els antics perfets sigmàtics. En el verb dir, en la tercera persona del singular predomina clarament el perfet fort dix (460 casos, 98'7\%) sobre el feble digué, que només es documenta sis vegades (1’3\%). També es manté en aquest verb el perfet sigmàtic de

\footnotetext{
${ }^{36}$ Ridruejo $(1985,445)$ troba que el valor d'irrealitat present de les formes de subjuntiu en -ra comença a documentar-se en valencià a mitjan segle XVI.
} 
tercera persona del plural dixeren (6 casos, 28'5\%), encara que en aquest cas ja predomina la forma velaritzada digueren (15 casos, 71'4\%). En el verb respondre conviuen respòs (9 casos, 34'61\%), tres vegades coordinat amb dix $(126,7 ; 130,16 ; 873,2)$, i respongué (17 casos, 63’38\%). Es documenta un cas del perfet de tercera persona pres $(92,20)$, en la narració de l'escrivà, però la resta de casos, en les declaracions dels testimonis i denunciants, es fa servir prengué (26 casos); promés $(92,20 ; 132,17)(2$ casos) en la narració de l'escrivà, i prometé (62, 21; 92, 10; 132, 2, 19, 20 , 23) (6 casos) en la narració de l'escrivà i en la declaració de l'acusat; requés $(62,15 ; 132,10)$, requirí $(811,2 ; 841,4 ; 849,2)$, tots dos en la narració de l'escrivà.

Quant als perfets forts en -I, la tercera persona del verb ésser és sempre la velaritzada fonch; en la tercera persona del verb veure es documenta habitualment veu $(62,8,10,11 ; 92,10 ; 118,4,8 ; 132,4$, 26; etc.) (< VĪDIT), amb la mateixa vocal que feu $(62,13,16,21)$ (< FĒCIT).

El verb vendre manté el perfet etimològic sense velaritzar vené $(883,3,8)$, que permet evitar l'homonímia amb vengué $(55,2)$, perfet de venir, que conviu amb vingué $(62,26,29 ; 92,4 ; 213,3)$, més utilitzat.

Notem les formes de perfet de tercera persona velaritzades afiggué (132, 7), fuiggué $(873,2)$, recullgué $(258,7 \mathrm{v})$, ixgué $(213,25)$ i el més usual ixqué $(213,4,6,12,14,17,21,25 ; 258,1 v)$, conjugades seguint el model dels perfets febles analògics en -DEDI. També presenta velarització empenygué $(873,5)$.

En una ocasió es documenta el perfet perifràstic va obrir: «estigueren en obrir dita porta molt gran estona e per espay de una hora o més fins tant que li digueren [d]e part de fora lo magnífich alguazir y verguetes que puix no sén podia exir, que obrís. E [...] lo dit Filibert, delat, deslligà dit picaport y va obrir dita porta» $(258,6 r)$. La perífrasi, inserida en una seqüència narrativa, està construïda $\mathrm{amb}$ un subjecte agent $\mathrm{i}$ un infinitiu de caràcter actiu, com ocorre en el primer estadi de gramaticalització (veg. PÉREZ SALDANYA: 1998, 261-275). 


\subsection{FUTUR I CONDICIONAL EN -RIA}

Encara que generalment apareixen fusionades les formes verbals de futur i condicional, originàriament analítiques, encara trobem el futur separable, amb el pronom feble intercalat entre el lexema i la desinència, en un fragment en estil directe que forma part d'un clam oral: «Sellavors, lo dit Francés Pons dix: "Donar-la-be la mia part a mon pare, puix és parçoner, y yo faré la fahena”» $(818,7)$. La presència precisament en un text en estil directe que forma part d'un diàleg sembla ser indici que aquest futur separable encara es podia sentir en la llengua parlada.

Es documenten algunes formes antigues de futur i condicional. En el verb poder predominen les formes etimològiques porà $(92,3 ; 118,18$; $126,4 ; 132,7 ; 147,4 ; 258,9 r)$, poran $(55,4 ; 62,23,24 ; 213,26 ; 261,7)$, poria $(132,5 ; 258,5 \mathrm{r}, 7 \mathrm{r} ; 883,10)$, molt més emprades que podran (92, $15)$, podrien $(55,2)$. En volrà $(92,19,28)$, volran $(92,27,132)$ encara no s'ha introduitt la $d$ epentètica.

Els futurs aparrà $(62,24)$ i comparrà $(62,35 ; 118,22)$, comparran $(213,32)$ corresponen als antics aparer i comparer, respectivament. En una ocasió es documenta comparan $(213,32)$, que podria explicar-se per influència de l'infinitiu comparer.

\subsection{FORMES NO PERSONALS DEL VERB}

Es documenen les formes ésser (56 casos, 88'88\%) i ser (7 casos, $\left.11^{\prime} 11 \%\right)$, però amb un predomini clar de la primera. En el gerundi només es documenta essent $(62,20 ; 118$, 3; etc.).

L'infinitiu comparrer $(118,21)$, variant de comparer, no registrat en els diccionaris històrics, deu explicar-se per analogia de les formes de futur comparrà, comparran.

Els verbs en -metre mantenen els infinitius i participis tradicionals i genuïns: admetre $(62,33 ; 62,34)$, cometre $(147,3)$, remetre $(62,18)$, admesa $(62,40)$, admeses $(62,34 ; 118,22)$, comés $(62,23 ; 92,14 ; 118,18)$, comesa $(92,15 ; 132,16)$, permés $(92,8 ; 118,16 ; 147,2)$. Es documenta també un participi arremés: «E lo dit Joan de Nave dix que havia trobat hun home que.s barallava ab aquella, lo qual, entrant ell en dita cambra, se era arremés ad aquell, y que dit home devia ésser orat o questava borra- 
cho» $(819,69)$, d'un verb arremetre, el qual, segons el DECat $(\mathrm{V}, 652)$, és un castellanisme per escometre. ${ }^{37}$

Són també tradicionals els participis comprés $(132,4)$, concebut (92, $11)$, jagut $(258,4 \mathrm{v})$, rebut $(92,3)$, rebuts $(55,4)$, romput $(92,2)$, l'antic participi fort de llegir, lest $(132,24)$, i els participis antics dels verbs seer i asseer: seyta: «seyta en terra» $(213,21)$, asseyta: «stant aquella aseyta en una cadira» $(62,12)$, «stava aseyta y plorant» $(845,6)$.

En el verb haver, juntament amb hagut $(126,2 ; 213,25)$, es documenta la variant haüt $(92,17 ; 147,8)$, també ben antiga.

Els participis de tenir i venir són, respectivament, tengut i vengut, normals en la llengua antiga.

En el gerundi de veure conviuen veent $(118,6 ; 258,1 v, 2$ r) i vent $(118,17 ; 126,3)$, més usat.

Les desinències dels gerundis de la segona conjugació són les tradicionals, sense extensió analògica de la velar, avui tan difosa en valencià: aprenent $(62,18)$, corrent $(62,7)$, dient $(62,21)$, regonexent $(62,6)$, rient $(845,6)$, trahent $(821,1)$.

El participi de present amb valor verbal és molt poc usat, i només el trobem en dues ocasions: «lo divendres proppassat contants vint-i-nou dies del proppassat mes de juliol» $(55,2)$, «renunciant encara a la ley, si convenerit, de jurisdictió de tot jutge e altre qualsevol dret, ley y privilegi, fur, ús, costum e constitució contra les dites coses venints» $(132,16)$. També conserva, almenys en part, el caràcter verbal regent en la construcció regent la Cancelleria, que es documenta diverses vegades, ex. «de provisió del molt magnífich micer Agostí Gallart, regent la Cancelleria de sa majestat» $(118,12)$, i que cal diferenciar del caràcter purament substantiu que té regent en: «Y stant en aquest debat, vingué lo regent del partit, y

\footnotetext{
${ }^{37}$ En canvi, en el DCVB es considera genuí, derivat de remetre. Encara que la majoria de testimonis documentals coneguts són del segle XVI o posteriors, es documenten alguns casos d'arremetre al segle XV (DCVB, CICA), i fins i tot al segle XIV es documenten les formes verbals arremeté (CICA: Clams II, p. 227, 1. 18), arremetut (CICA: Manual II, p. 413, 1. 26).
} 
dix a ell, dit testimoni, que.l portaria a la presó. Y ell, dit relant y testimoni, dix al dit regent del partit que.l portàs a la presó» $(819,2)$.

Tenen un major ús algunes formes procedents de participis de present desproveïdes de la funció verbal, que perduren com a substantius. Es tracta de termes característics del llenguatge jurídic, i més en particular, dels processos judicials: acusant: «al qual ell, relant e acusant, se reffir» $(62,3)$, clamant: «exint ell, dit clamant e relant, de casa de hun barber» $(92,2)$, confessant: «La dona na Ysabet Damiana, muller d'en Diego Morales, velluter, confessant, relant e testimoni, qui jura, etc., dir veritat, etc» $(62,25)$, denunciant: «E la dita na Loysa de Angulo, supplicant e denunciant qui dessús» $(62,16)$, relant, suplicant, proposant: «a dormir a casa de la dita proposant» $(55,3)$, constituent: «la dita Isabet Sagristana [...] féu e constituhí procurador seu cert y special [...] a l'honorable e discret en Johan Thorija, notari [...] per a que en nom d'ella e per ella, dita constituhent, puxa entrevenir e entrevinga en la present causa de denunciació» $(132,19)$.

\subsection{COMPORTAMENT SINTÀCTIC D'ALGUNS VERBS}

Destaquem alguns usos verbals que difereixen dels més comuns actualment.

Aferrar (d'algú) 'agafar-lo fort': «E lavors lo dit Martí Rodrigues y ell, testimoni, ajuntaren ab Joan Ros per aferrar de aquell, Y ell, testimoni, $\mathrm{ab}$ la força que dit Joan Ros feya, may lo pogué afferrar» $(118,14) \cdot{ }^{38}$ Es tracta d'un ús intransitiu del verb aferrar regint un complement amb la preposició de no registrat en els diccionaris històrics ni normatius. El trobem en altres textos dels segles XV i XVI, ex. «un capellà que la dita senyora té en casa nomenat mossèn Johan Sànchiz, aferrà per lo semblant del dit moro levant-lo al dit procurador» (1484-1499) (CICA: «Gandia» I, p. 64, 1. 7), «e ella, testimoni, volent-sén exir del dit carrascal e tornar en lo mateix camí, lo dit home lançà en terra una capa que portava e aferrà d'ella, relant e testimoni, e ab molta força lançà a ella, relant e testimoni, e la derrocà en terra» (1544) (ARV. Processos criminals. II part.

\footnotetext{
${ }^{38}$ Comprovem que en aquest text apareix també l'ús transitiu del verb aferrar.
} 
Caixa 3, exp. 31, p. 7), i referit a objectes: «pegant ab la axada, la gangalla de aquella aferrà de un drap de llens molt brut, e tirant descobrí.s lo argent» (1568) (CICA: Cantó, «Furt», p. 122, 1. 5). Més modernament el trobem com a pronominal, també amb la preposició de, aferrar-se (d’algú): «Ixqué com un cuet, rabicalenta i plena de fiçons i aferrant-se de son marit com una llepada» (CIVAL: Galiana, Rondalla de rondalles).

Coromines (DECat, III, 985) informa d'un ús intransitiu del verb aferrar amb la preposició amb a Eivissa, però diferent d'aquest: «tal lloc aferra amb sa Serra d'en Jaume». ${ }^{39}$ En el DIEC i el DNV aferrar-se, pronominal, 'agafar-se fortament a una cosa' (DIEC, DNV), 'no poder separar-se o deseixir-se (d'algú o d'alguna cosa)' (DIEC), 'unirse fortament a algú o a alguna cosa' (DNV), i aferrar, transitiu, 'fixar, subjectar'. En el DUVC aferrar [algú o una cosa] (a algú o una cosa) 'subjectar fort' i aferrar-se [a algú o una cosa] o bé [a + oració d'infinitiu] o bé [al fet que + oració].

En italià afferrare és transitiu i reflexiu, amb algun ús intransitiu especialitzat (GDLI, I, 202-203), en occità aferrar és transitiu 'prendre en main', 'accrocher, prendre de force, enferrer' i pronominal s'aferrar en 's'ancrer en' (DOF, DOM); ${ }^{40}$ en castellà, segons el DCECH (III, 356), aferrar és usat «casi siempre con significado náutico», i seria pres del català. Però també s'hi troba amb altres usos: ${ }^{41}$ aferrar transitiu 'agarrar o asir fuertemente' (DME), i intransitiu: aferrar (de alguien o de algo): «uno le hiere y otro de él afierra / y él se defiende y hace cruda guerra» (id., Jerónimo de Urrea: Traducción de Orlando furioso, 1549), «Quién, fal-

${ }^{39}$ Quant a l'origen del mot, segons el DECat (III, 985) i el DE, és un derivat de ferro. En canvi, segons el DCVB, procedeix del llatí *AFFĚrRARE. En el FEW el francés antic aferrer i l'occità aferrar se situen sota l'ètim *AFFĔRRARE (I, 49), però en un altre lloc (III, 475) se situen entre els derivats s. v. FERRUM.

${ }^{40}$ En francés ant. aferrer és rar (FEW, I, 49; III, 475). Segons Coromines (DECat. III, 985), és una formació ben genuïna en català, en occità i en italià. En canvi, segons el DOM, pel que fa a l'occità aferrar, hom pensarà més aviat en un manlleu de l'italià i del català que no en una formació autòctona.

${ }^{41}$ Segons el DCR (I, 229), en castellà el sentit fonamental és el nàutic 'asegurar con el ferro o ancla', «y de ahí salen los demás por extensión o metáfora». 
tándole tiros, luego afierra / del pedazo de remo o de la entena» (id., Alonso de Ercilla: La Araucana, 1578), aferrar en: «llevan un asta de lança é en cabo un rallón con orejas, que, quando entra, aprieta, é al tirar, afierra en la carne» (CDH: Pero Tafur: Andanças e viajes, c. 1457), afe$\operatorname{rrar}$ (con alguien): «Después vino el rey de Francia a la guerra de la Lombardía, y como fuese vencido y preso por los españoles en el Parco de Pavía, siendo Diego Dávila y otros cuatro los que primero aferraron con él» (id., Juan de Pineda: Diálogos familiares de la agricultura cristiana, 1589), aferrar (una nave) (con otra nave): «La nao capitana debe mucho trabajar de no aferrar con otra, porque entonces no podría ver lo que pasa en la batalla ni proveer en ello» (id., Alonso de Chaves: Espejo de navegantes, c. 1527). ${ }^{42}$

A diferència de l'ús normatiu actual (DIEC, DNV, DUVC), amenaçar és intransitiu, i regeix un complement indirecte: «venint ella, clamant, poch ha, a demanar justícia, estant en la Seu retret, lo dit Sancho Navarro li amenacà a ella, clamant, e a hun altra filla sua que venia ab ella» (213, 4). Segons Coromines (DECat, V, 568), amenaçar (i menaçar) va ser intransitiu «en tota l'època arcaica [...], en tot el català antic i clàssic», i en cita exemples fins al segle XV. Amb l'exemple del nostre procés comprovem que al segle XVI encara s'usava com a intransitiu, si bé també sén coneixia l'ús transitiu: «lo dit Batiste Lopis lo amenaçà que.l mataria a coces» $(813,1)$. En castellà antic, seguint la construcció llatina amb datiu de persona mortem alicui minari, figurava sovint com a acusatiu «la palabra que significa el daño que se anuncia», i anava en datiu «el nombre de la persona», i també sense acusatiu, podia usar-se el datiu per a expressar «la persona o cosa a quien va a sobrevenir el daño» (DCR, I, 422-423). L'italià minacciare també pot ser transitiu i intransitiu (GDLI).

Demanar (d'algú) 'preguntar o interessar-se (sobre algú)': «y com no.l trobàs en dita casa, y demanant de aquell, li sia stat dit que no y era, ha citat aquell ab ralla a les portes de la casa de aquell, hon aquell solia star, habitar y revenir per a demà en hora de Audiència» (62, 32).

${ }^{42}$ Vg. també el DCR (I, 229-231). 
Els diccionaris normatius i descriptius recullen aquest verb, amb aquest sentit, regint un complement introduït amb la preposició per (demanar per algú) (DIEC, DNV, DDLC, DUVC). Coromines (DECat, $\mathrm{V}, 411$ ) afirma que en català antic «era corrent introduir la cosa demanada amb de en lloc de dir 'preguntar per'». En el nostre cas veiem aquest ús també per referència a una persona.

El verb ajudar en els processos estudiats és intransitiu: ajudar (a algú): «de les quals tem morir si la Gràcia de Nostre Señor Déu no li ajuda e remedia» $(92,3)$, «e a tot e qualsevol altre fur, ley, privilegi, ús, costum e constitució que contra les dites coses venir e ajudar li pogués» $(92,17)$, «lo qual per ajudar-li li esgarrà tot lo sayo» $(841,2)$. Els diccionaris normatius el recullen com a transitiu (ajudar [algú]) (DIEC, DNV), ${ }^{43}$ però, com afirma Coromines (DECat, I, 116), en l'edat mitjana era intransitiu, ${ }^{44}$ com en altres llengües romàniques.

Igualment, trobem el verb evadir usat com a intransitiu, no pronominal, regint un complement introduït per la preposició de, indicador del lloc, la situació o la persona d’on hom s'allunya o fuig: «E ab les spases desembainades, impediren al dit alguazir que no pogués pendre al dit Joan Ros, per hon aquell tingué forma de evadir de les mans del dit alguazir e anar-sén de la dita casa» $(118,17){ }^{45}$ Els diccionaris històrics i normatius catalans només recullen evadir com a transitiu o pronominal.

\footnotetext{
${ }^{43}$ També en el DUVC.

${ }^{44}$ Segons aquest filòleg, l'ús intransitiu d'ajudar «continua tenint fins avui molta més extensió del que es creu generalment; sobretot a Mallorca». El documentem també en valencià als segles XIX i XX, ex. «baix lo pretext / [...] de achudar-li» (Roquet y Goriet, València, 1809, p. 3), «Ma mare duya tarea / als seus añs molt superior; / li achudaré a la vellea» (Alberola: Refranera valenciana, València, 1927, p. 20), «y com és tan vergoñós y sap que yo sóc tan amiga seua, pués vol que yo li achude» (Hernández Casajuana: ¡No és per abí...!, València, 1927, p. 12).

${ }^{45}$ Trobem evadir de en un altre text del segle XVI: «se entengué que Garcia de Velasco, que havia comès dit frau, per evadir de la pena encomanà la dita quantitat al prior don Hernando» (1585) (CICA: «Corts», p. 629, 1. 32).
} 
Ara bé, en llatí EVADERE era intransitiu, i així es troba també en altres llengües romàniques. ${ }^{46}$

El verb donar regeix l'infinitiu fugir (fogir) amb les preposicions a i de, donar a (de) fugir: «lo qual home que li pegà y donà a fugir és hun home gran» $(819,2)$, «A les quals coltellades donaren de fogir lo dit Angulo y son amich» $(92,12)$. En el DCVB es registra donar 'executar, fer una acció, però no s'hi recull l'ús del verb donar amb fugir. No figura tampoc en el DIEC, en el DNV, en el DDLC ni en el DUVC. Amb la preposició a el trobem en altres textos dels segles XVI i XVII: «ell, dit confessant, vora mar, dona a fugir» (CIVAL: Jaume Terres, 1544), «Diumenge, a 8 de giner 1617, [...] donà a fugir y lo evadit corregué darrer de l'invasor»(CIVAL: Porcar: Coses evengudes). També es troba en uns processos del segle XVI de la Ribera del Xúquer (BARBERÀ: 2018, 542), i en un procés de Lleida del mateix segle (FARRENY: 2004, 298).

Farreny (2004), davant l'absència d'aquest ús de donar en les fonts consultades, pensa «en el paral.lel castellà darse a la fuga». No oblidem, però, que, com demostra Coromines (DECat, III, 24), en català antic es documenten diverses construccions amb donar (o dar), que avui s'expressarien amb altres verbs, com pegar o fer. Entre aquestes construccions antigues amb donar, en el DECat es recull donar un cop, cops, i anàlegs, «ja ben antics». En relació amb això, en alguns dels nostres processos documentem també donar una punyalada o de punyalades (o de coltellades), ex. «ab la dita delliberació que havien fet e delliberat entre si de fer donar de punyalades a la dita Catherina Paes e de Portugués» (62, 21), «entre les persones que tenen notícia de la dita punyalada que lo dit Pere Millà ha donat a la dita Catherina Paes e de Portugués» (62, 23), «anant a pasejar lo dit Angulo en companya de Alonso Ortega, amich seu, los

${ }^{46}$ És el cas de l'italià evàdere (GDLI, V, 517), del francés antic évader 'échapper à' (DHLF, DEHF). En castellà el DCR (III, 1206) recull l'ús d'evadir-se de només com a reflexiu, però es pot comprovar que també hi ha documentació antiga en aquesta llengua d'evadir de, ex. «conformándose al común uso a tiempo por evadir de las asechanças de vanagloria» (CORDE: Enrique de Villena: Traducción y glosas de la Eneida. Libros I-III, 1427-1428), «Tú te fatigas en vano / por mal arte, / y no puedes escusarte / ni de gran culpa evadir» (CORDE: Torres Naharro: Comedia Calamita, 1520). 
hixqueren dos hòmens y començaren ha donar en ells de coltellades» (92, $12)$, juntament amb pegar: «havent pegat aquell dita punyalada» $(62,8)$, «dix que si ell haguera tengut hun punyal, haguera pegat de punyalades al dit alguazir» $(118,8)$, i fins i tot poden aparéixer tots dos formant un grup sinonímic: «aquell, dit en Pere Millà, ha donat e pegat la dita punyalada a la dita Catherina Paes e de Portugués» $(62,23) .^{47}$

Encontrar ( $a b$ algú) 'topar, coincidir (amb algú) (en un lloc)': «essent ell, dit relant e testimoni, en lo carrer dels Cadirers de la present ciutat, anant en companyia de ell, dit relant e testimoni, Domingo Rodrigues, Martí Rodrigues, Joan de Miedes e Blay Ramos, verguetes, [...] encontraren ab hun germà de Ros» $(118,2)$, «y essent en lo carrer dels Cadirers de la present ciutat, defront del forn que stà en dit carrer, encontraren ab hun jove desbarbat» $(118,7){ }^{48}$

Amb aquest sentit els diccionaris històrics, normatius i descriptius recullen encontrar com a pronominal o com a transitiu, però no com a intransitiu regint un complement amb la preposició ab (DIEC, DNV, DDLC, DCVB, DECat), com apareix en aquest procés. Cal dir, però, que es troba en altres textos dels segles XVI i XVII (vg. CIVAL). ${ }^{49}$

Juntar (ajuntar) (ab algú) 'reunir-se (amb algú)', ex. "Y essent entrat en lo carrer de la Avallada de Sent Francés, davant una tenda, veu ell, testimoni, que al passar de la porta de la dita tenda, [...] junctà bun bome ab la dita Portoguesa, e dix: "O, cap de tal" [...] e li pegà ab hun punyal hun colp en los pits» $(62,8)$, «Y a huyt o deu pases, staven $\mathrm{d}[\mathrm{os}]$ hòmens parats, y lo dit Milà ajunctà ab aquells. E los tres se n'anaren per la plaça de Senct Francesch» (62, 8), «E havent encontrat ab aquell, los dits Martí Rodrigues e Domingo Rodrigues, verguetes, ajuntaren ab aquell» (118,

\footnotetext{
${ }^{47}$ Igualment, en uns processos criminals de la Ribera conviuen pegar i donar una caiguda: «caygué davant de aquells pegant en terra gran [d] issima cayguda», "Y, essent davant de la dita testimoni [...], donà una gran cayguda en terra» (BARBERÀ: 2018, 41, 43).

${ }^{48}$ Es troba també en altres processos criminals de l'època, ex. «Y en lo camí, ans de arribar a València, encontraren ab lo dit Nicolau Serra, lo qual les acompanyà fins a casa» (1574) (ARV. Processos criminals. II part. Caixa 30, exp. 286, p. 107).

${ }^{49}$ Es coneix també en castellà l'ús intransitiu d'encontrar amb la preposició con (DCR: III, 343).
} 
3), diferenciat semànticament d'encontrar (vg. més amunt), «lo dit alguazir $y$ verguetes ajuntaren ab aquell per regonéxer-lo y mirar quines armes portava» $(118,16)$, «Y sellavors ell, dit testimoni, junctà ab lo dit Francés Pons y l'entrà en lo carreró» $(818,4)$.

Els diccionaris recullen ajuntar-se (algú) (amb algun altre) 'reunir-se (ab algú) (en un lloc)' com a intransitiu i pronominal (DIEC, DDLC, DNV, DUVC), però no únicament com a intransitiu. ${ }^{50} \mathrm{~A}$ pesar de tot, aquest ús intransitiu es troba també en altres textos dels segles XVI i XVII, ex. «Corneli Scipió juntà ab los enemichs» (CICA: Beuter, «Història», p. 117, 1. 5), «no esperà que s'ajustassen les gents de tota Spanya, sinó que $\mathrm{ab}$ los que.s trobà entorn anà ajuntar ab los enemichs a Xerez» (id., p. 160, 1. 31), ${ }^{51}$ «Lo duch y conte y almirant y don Pero Maça juntaren ab lo virrey» (1521) (CIVAL: La Germania a Gandia $i$ el duc Joan de Borja), «lo dit Luís Rodrigo ajunta ab ell, relant y li posà los genolls sobre el ventre» (CIVAL: Antoni de la Tàpia 15-07-1621).

Saber lo nom (a algú): «Y estant en sa casa, vingueren en dita casa hun traginer que stà al carrer d'En Usall, a la porta falsa de Borrell, al qual no sab lo nom, y hun home que stà en Ruçafa que fa bacines, y altres dos o tres que eren veng[ut]s en sa casa per a beure, als quals no sab lo nom» $(845,6)$, «e questà en veritat qu+en lo dia de hir llogà per a pastar a hun jove flaquer gavaix que no li sab lo nom» $(873,3){ }^{52}$

Actualment s'hi faria servir la preposició de, que, de fet, es troba ja des d'antic, ex. "Car Jesuchrist axí bé sabia lo nom del rich com del pobre» (CIVAL: Sant Vicent Ferrer, Sermons), «de la qual no sab lo nom ni de son marit» (1523) (CIVAL: La Germania a Gandia i el duc Joan de Borja).

\footnotetext{
${ }^{50}$ Coromines (DECat, IV, 923) afirma que en català és «més normal ajuntar» que juntar.

${ }^{51}$ En la Primera part de la Història de València (1538) de Beuter n'hi ha diversos casos més.

${ }^{52}$ Cf. ser-li amic (o enemic) (a algú): «E dix que no li és estat may enemich, sinó amich y molt gran ell, dit confessant, e que jamés ha tengut paraules ni baralles ab aquell, ans tostemps li és estat amich» (BARBERÀ: 2018, 161).
} 
BIBLIOGRAFIA

ALEGRE, Montserrat (2007): Diàlegs de sant Gregori. Estudi lingüístic de la versió catalana de 1340, Barcelona, PAM.

BADIA I MARGARIT, Antoni M. (1981): Gramàtica bistòrica catalana, València, Ed. Tres i Quatre.

BARBERÀ I IBIZA, Joan (2018): El català de la Ribera del Xúquer al tombants del segle XVI (1570-1599). Edició $i$ estudi lingüistic d'onze processos criminals, tesi doctoral dirigida pel Dr. Emili Casanova, València, Universitat de València.

Beltran Calvo, Vicent \& Carles Segura-Llopes (2017): Els parlars valencians, València, PUV.

CALLADO, Emilio et al. (2018): L'episcopologi valencià de Gregori Ivanyes (segle XVI). Estudi i edició, València / Barcelona, IIFV / PAM.

CANO I IVOrRA, Ma Antònia (1995): El Llibre del Mostassaf d'Elx. Edició crítica i estudi lingüistic, Alacant, Institut de Cultura Juan Gil-Albert.

CASANOVA, Emili (1989): «Gramàtica històrica i història de la llengua. A propòsit de l'evolució de la desinència de $1^{\text {a }}$ persona del present d'indicatiu», en Antoni FERRANDO (ed.), Segon Congrés Internacional de la Llengua Catalana. Àrea 7. Història de la Llengua, València, IFV, p. 343-357.

- (1993): «Evolució i interferència en el sistema demostratiu català: una explicació», en Actes del Novè Col.loqui Internacional de Llengua $i$ Literatura Catalanes (Vol. III), Barcelona, PAM, p. 161-195.

- (2003): «L'evolució de l'article onomàstic "En/ $\mathrm{Na}$ " en català i occità», en Fernando SÁNCHEZ MIRET (coord.), Actas del XXIII Congreso Internacional de Lingüistica y Filología Románica (Vol. 2), Tübingen, Max Niemeyer Verlag, p. 209-234.

CAStaño i GarCiA, Joan \& Antoni MAS i Miralles (2015): Llibre de la fábrica de Senta Maria de la vila de Elig (1592-1699), Alacant, Universitat d'Alacant.

$\mathrm{CDH}=$ INSTITUTO RAFAEL LAPESA: Corpus del Nuevo diccionario histórico del español. <http://www.frl.es/Paginas/default.aspx> 
CICA = Torruella, Joan, Manuel Pérez SAldanya \& Josep MARTINES: Corpus Informatitzat del Català Antic. $<$ http://cica.cat/index.php $>$

CIVAL $=$ ACADÈMIA VALENCIANA DE LA LlenguA: Corpus Informatitzat del Valencià. <http://cival.avl.gva.es/cival/buscador. jsp>

COLÓN, Germà \& Arcadi GARCIA (1987): Llibre del Consolat de Mar. Vol. IV. Estudi filològic i indexs, Barcelona, Fundació Salvador Vives Casajuana.

COROMINES, Joan (1983): Lleures i converses d'un filòleg, Barcelona, Club Editor.

CORDE = REAL ACADEMIA ESPAÑOlA: Banco de datos (CORDE) [en línea]. Corpus diacrónico del español. <http://www.rae.es>

DAg = Diccionari Aguiló (1915-1934), Barcelona, IEC.

DCR = CuERVO, Rufino José (1992-1994): Diccionario de construcción y régimen de la lengua castellana, Bogotà, Instituto Caro y Cuervo.

DCVB = Alcover, Antoni M. \& Francesc de B. Moll (1988): Diccionari Català-Valencià-Balear, Palma de Mallorca, Moll.

DDLC = INSTITUT D'ESTUDIS CATALANS: Diccionari descriptiu de la llengua catalana. <http://dcc.iec.cat/ddlc/scripts/index1.asp>

DE = BRUGUERA, Jordi (2006): Diccionari etimologic, Barcelona, Enciclopèdia Catalana.

DECat = COROMINES, Joan (1988-1991): Diccionari etimologic $i$ complementari de la llengua catalana, Barcelona, Curial.

DEHF = DUbOIS, Jean, MitTERAND, Henri \& Albert DAUZAT (2011): Dictionnaire étymologique et historique du français, París, Larousse.

DHLF = REY, Alain (dir.) (2006): Dictionnaire historique de la langue française, París, Le Robert.

DIEC = INSTITUT D'ESTUDIS CATALANS (2000): Diccionari de la llengua catalana. Barcelona/Palma/València: 3i4/Ed. 62/Moll/Enciclopèdia Catalana/PAM. 
DiéGueZ Seguí, Ma Àngels (2001): El Llibre de Cort de Justícia de València (1279-1321), Alacant/Barcelona, IIFV/PAM.

DME = Alonso, Martín (1986): Diccionario medieval español, Salamanca, Universidad Pontificia de Salamanca.

DNV = ACADÈMIA VALENCIANA DE LA LlENGUA: Diccionari normatiu valencià. <http://www.avl.gva.es/dnv>

DOF $=$ ALIBERT, Louis (2002): Dictionnaire occitan-français, Toulouse, IEO.

DOM: Dictionnaire de l'occitan médiéval, Institut de Philologie romane de l'Université de Munich. <http://www.dom-en-ligne.de/>

DuARTe, Carles \& Àlex AlSiNA (1986): Gramàtica bistòrica del català (Vol. 2), Barcelona, Curial.

DUVC $=$ GINEBrA, Jordi \& Anna MonTSERRAT (2009): Diccionari d'ús dels verbs catalans, Barcelona, Educaula.

ESCARTÍ, Vicent Josep \& Josep RIBERA (2019): El Llibre de memòries de la ciutat de València (1308-1644), València, Ajuntament de València.

FARRENY, Maria Dolors (1986): Processos de crims del segle XV a Lleida: Transcripció i estudi lingüístic, Lleida, IEI.

- (2004): La llengua dels processos de crims a la Lleida del segle XVI, Barcelona, IEC.

FEW = VON WARTBURG, Walther (1928-2002): Französisches Etymologisches Wörterbuch, Basel, Zbinden.

FRESQUET FAYOS, Rafael (1997): Vint processos criminals d'Albalat de la Ribera (1611-1666), Albalat de la Ribera, Ajuntament d'Albalat de la Ribera.

Garcia SEmpere, Marinela (dir.) (2013): El Libre de caça, Alacant/Barcelona, IIFV/PAM.

GDLI: Battaglia, Salvatore (1970-2002): Grande dizionario della lingua italiana, Torí, Unione Tip. Editrice Torinese.

GHLC: Batlle, Mar et al. (2016): Gramàtica històrica de la llengua catalana, Barcelona, PAM. 
Giralt LATORRE, Javier (2012): La llengua catalana en documentació notarial del segle XVI d'Albelda (Osca), Osca, Ajuntament d'Albelda.

GLC = Gramàtica de la llengua catalana, Barcelona, IEC.

MARTí, Joaquim (1991): Les Ordinacions de la costa maritima del regne de València (1673), Barcelona, IFV/PAM.

- (1992): «Unes ordenances del càrrec de sotssagristà de la Seu de València dels segles XVI i XVII. Edició i notes lingüístiques», Revista de Llengua i Dret, núm. 18, p. 25-66.

- (1994): El Libre de Antiquitats de la Seu de València. Estudi i edició, València/Barcelona, IFV/PAM.

- (2012): «Aspectes de morfologia nominal en el Curial e Güelfa», en Antoni FERRANDO FRANCÉS (ed.): Estudis lingüistics i culturals sobre Curial e Güelfa, Amsterdam/Philadelphia, John Benjamins, p. 597-630.

MArTí, Joaquim \& Xavier Serra (2009): La Consueta de la Seu de València dels segles XVI-XVII, València, Facultad de Teología San Vicente Ferrer.

Martín MiñanA, Pau \& Emili CASANOVA (2015): «La creació i l'evolució dels pronoms reforçats en català: una explicació», en Manuel PÉrez Saldanya \& Rafael RocA (eds.), Actes del XVIIè Colıloqui de l'AILLC, Barcelona/València, AILLC/IEC, p. 137-157.

Miralles MONSERRAT, Joan (1984): Un llibre de cort reial mallorqui del segle XIV, Mallorca, IEB/Moll.

Moll, Francesc de B. (2006): Gramàtica històrica catalana, València, PUV.

MONTOYA, Brauli (1990): «Un repte per a la lingüística històrica: copsar la llengua parlada del passat», Caplletra, núm. 6, p. 71-88.

NARBONA ViZCAÍNO, Rafael (1990): Malhechores, violencia y justicia ciudadana en la Valencia bajomedieval, València, Ajuntament de València.

PAR, Anfós (1928): «Curial e Güelfa». Notes lingüistiques $i$ d'estil, Barcelona, Balmes. 


\section{Revista de Filologia}

PÉReZ Saldanya, Manuel (1998): Del llatí al català. Morfosintaxi verbal bistòrica, València, Universitat de València.

RABELlA, Joan Anton (1998): Un matrimoni desavingut $i$ un gat metzinat. Procés criminal barceloní del segle XIV, Barcelona, IEC.

RAMOS, Joan-Rafael (2006): «Els auxiliars dels temps compostos en català medieval», Caplletra, núm. 38, p. 179-209.

RIDRUEJO, Emilio (1985): «La forma verbal en -ra en valenciano», en Actes du VIIème Congrès International du Linguistique et Philologie Romanes (Vol. 2), Aix-en-Provence, Université de Provence, p. 439-448.

SARAGOSSÀ, Abelard (2000): «Els adjectius possessius», Llengua E Literatura, núm. 11, p. 199-280.

SCHMID, Beatrice (1988): Les «traduccions valencianes» del Blanquerna (València 1521) i de la Scala Dei (Barcelona 1523). Estudi lingüístic, Barcelona, Curial/PAM.

SEgurA-LlopeS, Carles (2015): «L'evolució de la forma verbal cantara en català: un estudi de corpus», Mirabilia/MedTrans, núm. 1, p. $1-45$.

WHEELER, Max W. (2012): «La morfologia verbal al Curial e Güelfa», en Antoni FERRANDO FRANCÉS (ed.): Estudis lingüistics i culturals sobre Curial e Güelfa, Amsterdam/Philadelphia, John Benjamins, p. 875-908. 